\title{
EFEKTIVITAS PELAKSANAAN PROGRAM SEKOLAH GRATIS DI KOTA PALEMBANG PROVINSI SUMATERA SELATAN (Studi di SMA Negeri 16 Lebak Murni Kota Palembang)
}

\author{
Emmy Deseri \\ Badan Pengembangan SDM Daerah \\ Email: emmydeseri@yahoo.com
}

\begin{abstract}
ABSTRAK
Tujuan penelitian adalah untuk Mendiskripsikan serta mengkaji peran pemerintah kota Palembang dalam melaksanakan program sekolah gratis di SMA Negeri 16 Lebak Murni Kota Palembang, Mendiskripsikan serta mengkaji kendala kendala yang dihadapi pemerintah kota palembang dalam melaksanakan program sekolah gratis di SMA Negeri 16 Lebak Murni Kota Palembang. Dalam rangka memperolehilmu,khususnya Ilmu Administrasi Publik.

Penelitian ini merupakan penelitian kualitatif. Adapun tempat penelitian ini dilakukan di sekolahsekolah yang terdapat di kota Palembang khususya di SMA Negeri 16 Lebak Murni. Penelitian ini membahas tentang efektivitas pelaksanaan sekolah gratis dikota Palembang. Hasil penelitian ini antara lain Belum efektifnya pelaksanaan Permedagri nomor 13 Tahun 2006 yang dirasakan mekanismenya berbelit. Belum efektifnya Standar Pelayanan Minimum di SMA Negeri 16 Palembang. Belum efektifnya Penyediaan sarana dan prasarana pendidikan di SMA Negeri 16 Palembang. Belum efektifnya pengembangan dan pembinaan berkala dari Tim Provinsi ke kabupaten/Kota serta Tim Kabupaten/Kota ke tim Manajemen Sekolah ke sekolah SMANegeri 16 Palembang. Belum efektifnya pengawasan ke SMA Negeri 16 Palembang tentang penggunaan sekolah gratis. Belum efektifnya sangsi yang tegas pada kabupaten Kota yang tidak melaksanakan MOU dana Sharing dengan Kabupaten dan belum satu formnya sekolah sekolah sehingga masih ada sekola yang menolak program sekolah gratis yang di programkan pemerintah provinsi.
\end{abstract}

Kata Kunci : Efektivitas, Sekolah Gratis

\section{PENDAHULUAN}

\subsection{Latar Belakang}

Sejak Maret 2009 pendidikan di Sumatera Selatan Gratis.Artinya, ada beberapa komponen biaya pendidikan Sesuai dengan PP nomor 48 tahun 2008 tentang pendanaan pendidikan menjadi tanggungjawabbersama antara pemerintah, pemerintah daerah dan masyarakat. Biaya satuan pendidikan adalah biaya penyelenggaraan pendidikan pada tingkat satuan pendidikan yang meliputi:

1.,Biaya investasi, 2.Biaya Operasional. 3. Biaya pribadi.

Unit cost Program Sekolah Gratis per siswa pertahun yang berasal dari dana
APBD Provinsi dan Kabupaten/Kota adalah sebagai berikut:

1. SD/MI persiswa/tahun $=$ Rp. 120.000.-

2. $\mathrm{SMP} / \mathrm{MTS}$ persiswa/tahun $=\mathrm{Rp}$. 180.000.-

3. SMA/MA persiswa/tahun = Rp.1.200.000,-

4. SMK Tehnik persiswa/tahun = Rp.2.400.00,-

5. SMK Non Tehnik persiswa/tahun $=\mathrm{Rp}$. 1.836 .000

Dengan demikian, sebenarnya Program Sekolah Gratis secara nyata merupakan implementasi Program Wajib Belajar 12 tahun sebagai lanjutan dari program nasional wajib belajar 9 tahun. 
Adapun penggunaan dana Program sekolah Gratis. Sehingga orang tua hanya menyediakan biaya yang semestinya dia keluarkan. Sumatera Selatan adalah salah satu provinsiyang berani melaksanakan Program Sekolah Gratis dan menambahkannya untuk Program Kuliah Gratis ke Perguruan Tinggi Negeri dan Swasta baik jenjang S 1 S 2 .Seperti kita ketahui bahwa Program Sekolah Gratis pada tahun 2010mendapat anugerah Museum Rekor Indonesia (MURI). Pola keberhasilan Program Sekolah Gratis di Sumatera Selatan ini dalam menghantarkan kecerdasan anak bangsa,telah banyak dipelajari untuk dijadikan pedoman oleh Pemerintah Daerah Provinsi di Indonesia.

Kita sadari bahwa program sekolah gratis di Sumatera Selatan lahir dari sebuah proses politik yang mahal yang tentunya berpihak kepada rakyat banyak, merupakan program unggulan atau lebih tepat dikatakan janji kampanye calon gubernur yang telah dimasukkan dalam agenda kerja gubernur 2008-2013. Karena itu pelaksanaan program sekolah gratis Harus didukung sampai Kabupaten/ Kota di lingkungan Provinsi Sumatera Selatan, Meskipun dalam pelaksanaannya masih belum sempurna.

Sementara itu Tim Monitoring dan Evaluasi Program sekolah Gratis Provinsi Sumsel tahun 2013 dengan keputusan Gubernur Sumsel nomor 483/KPTS/Disdik/2013 tanggal 12 Juni 2013 yang tugas fungsinya melaksanakan Monitoring dan Evaluasi Program Sekolah Gratis ,melakukan Verifikasi setiap pengaduan masyarakat terkait penyaluran dan penggunaan dana Program Sekolah Gratis yang pelaksanaan tugasnya bertanggungjawab kepada Gubernur melalui kepala Dinas Pendidikan Provinsi
Sumsel belum maksimal memberikan kontribusi terhadap pelaksanaan Program Sekolah Gratis dikota metropolitan Palembang.

Dari 22 jumlah sekolah SMA yang tersebar dikotaPalembang ,maka salah satu yang menjadi lokus penelitian adalah SMA Negeri 16 Jalan Lebak Murni Sako Palembang, adapun alasan pemilihan lokasi penelitian dikarenakan wilayah sekolah berada dipinggiran kota Palembang dengan penduduk yang tergolong pendapatannya rendah serta siswa yang ada di SMA Negeri 16 Palembang berjumlah 635 siswa yang berdomisili diwilayah kecamatan sako sebagai kecamatan yang mulai berkembang.alasan lainnya SMA Negeri 16 Lebak Murni terakreditasi B Plus.

Berangkat dari $\begin{array}{r}\text { pemikiran } \\ \text { melakukan }\end{array}$
diatas,Makapeneliti
penelitianlebih lanjut tetntang pelaksanaan Program Sekolah Gratis di SMA negeri 16 Lebak Murni Kota palembang,peneliti akan memotret fenomenapelaksanaan program sekolah gratis yang ada dilingkungan sekolah yang berpedoman dengan Perda No. 3 tahun 2009 dan Pergub No. 31 tahun 2009 dan pelaksanaan Perwali Nomor 22 tahun 2011 tentang besaran /satuan biaya dana bantuan /Komite sekolah. yang menurut peneliti belum efektif pelaksanaannya. Hal ini dapat dilihat dari besaran dana yang diterima persiswa sebesar Rp. 87.000 persiswa perbulan, jumlah ini jauh lebih kecil dari seharusnya sebagaimana diatur dalam Pergub nomor 31 tahun 2009 sebesar Rp. 1.200.000. sedangkan dana sharing kota Palembang yang telah disepakati bersama pemerintah Provinsi dan Kota untuk Program Sekolah Gratis tidak berjalan. Melalui tulisan ini peneliti berharap akan membuka suatu wacana 
baru yang menarik untuk mengembangkan Program Sekolah Gratis di kota Palembang.

\subsection{Rumusan Masalah}

Berdasarkanuraian

latarbelakangmasalahdan sebelum peneliti mengemukakan research question, terlebih dahulu akan mengemukakan "problem statement", yaitu:Bagaimana Efektivitas pelaksanaan Program Sekolah Gratis di

SMA Negeri 16 Lebak Murni Kota Palembang Provinsi Sumatera Selatan?

\subsection{Maksud dan Tujuan Penelitian}

Dengan mengacu pada latar belakang dan perumusan masalah diatas, makamaksud dan tujuan dalam penelitian ini adalah sebagai berikut:

1. Mendiskripsikan serta mengkaji peran pemerintah kota Palembang dalam melaksanakan program sekolah gratis di SMA Negeri 16 Lebak Murni Kota Palembang

2. Mendiskripsikan serta mengkaji kendala kendala yang dihadapi pemerintah kota palembang dalam melaksanakan program sekolah gratis di SMA Negeri 16 Lebak Murni Kota Palembang

3. Dalam rangka memperoleh konsep baru bagi perkembangan ilmu, khususnya Ilmu Administrasi Publik.

\subsection{ManfaatPenelitian}

Adapun manfaat dalam penelitian ini adalah sebagai berikut:

1. Manfaat penelitian dari Aspek teoritis adalah memberikan masukan pada dunia pendidikankhususnya jurusan administrasi publik untuk mengembangkan lebih lanjut Program Sekolah Gratis sebagai salah satu fungsi hakiki pemerintah serta mendorong peneliti lain untuk melakukan penelitian tentang kelanjutan program sekolah gratis.

2. Manfaat penelitian dari Aspek praktis, hasil penelitian ini dapat dimanfaatkan dan dijadikan referensi oleh para pejabat birokrasi dan politisi untuk pembuat kebijakan dan pengambilan keputusan pemerintah daerahkhususnya efektivitas pelaksanaan program sekolah gratis di Kota Palembang Provinsi Sumatera Selatan.

\section{TEORI}

\subsection{Efektivitas}

Efektivitas merupakan unsur pokok untuk mencapai tujuan dan sasaran yang telah ditentukan didalam setiap organisasi ,kegiatan ataupun program. Disebut efektif apabila tercapai tujuan ataupun sasaran seperti yang telah ditentukan. Hal ini menurut pendapat $\mathrm{H}$. Emerson yang dikutif Handayaningrat (1994:16) yang menyatakan bahwam"efektivitas adalah pengukuran dalam arti tercapainya tujuan yang telah ditentukan sebelumnya .

Penelitian kepustakaan yang ada mengenai teoriefektivitas memperlihatkan keanekaragaman dalam hal indikator penilaian tingkat efektivitas suatu hal. Hal ini terkadang mempersulit penelaahan terhadap suatu penelitian yang melibatkan teori efektivitas, namun secara umum, efektivitas suatu hal diartikan sebagai keberhasilan dalam pencapaian target atau tujuan yang telah ditetapkan.

Efektivitas memiliki beragam jenis, salah satunya adalah efektivitas organisasi. Sama halnya dengan teori efektivitas secara umum, para ahli pun memiliki beragam pandangan terkait dengan konsep efektivitas organisasi.Ndraha (dalam Makmur, 2008:124).“ 


\section{Model Dimensi Waktu dari Efektivitas}

Gibson (1996 : 51)

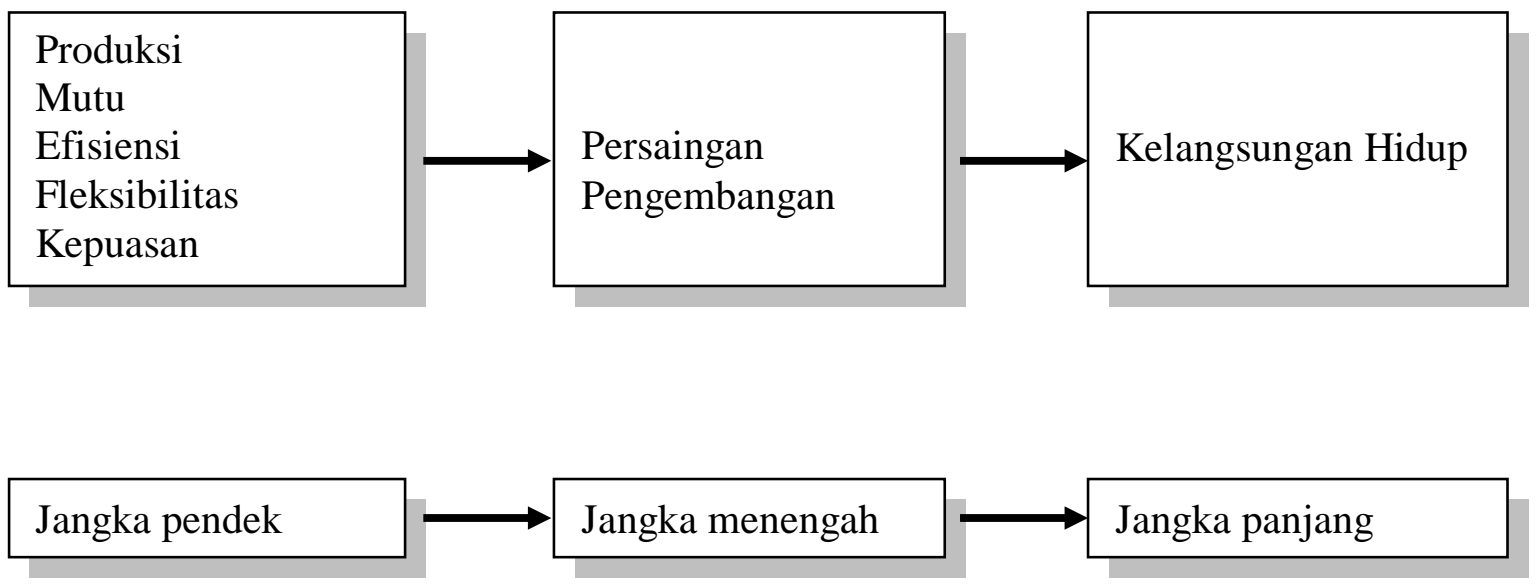

Dari pendapat yang dikemukakan oleh para ahli tersebut, maka dapat disimpulkan bahwa yang menjadi penekanan dari pengertian efektivitas ini pada pencapaian tujuan atau sasaran yang dikehendaki dapat tercapai sesuai dengan rencana semula dan menimbulkan dampak terhadap apa yang diinginkan atau diharapkan.

\subsection{Pengertian Program Sekolah Gratis}

Program adalah serangkaian tindakan atau aktivitas untuk dapat melaksanakan sesuai dengan target rencana yang telah ditetapkan. Untuk melaksanakan suatu pekerjaan tertentu diperlukan penyusunan program yang mantap agar pekerjaan yang dilakukan lebih terarah, efektif dan efisien dalam memanfaatkan semua sumber daya yang dibutuhkan.

Sasaran program sekolah gratis adalah setiap Siswa mulai dari jenjang SD/SDLB/MI,SMP/SMPLB/MTs, SMA/S

MALB/MA/SMK baik negeri maupun swasta, termasuk SSN,RSBI dan SBI kecuali kelompok belajar paket (Paket A,B dan C) serta Pendidikan Diniyah.

Program Sekolah Gratis yang dibiayai dengan sharing dana dari APBD Provinsi dan Kabupaten/Kota dimaksudkan untuk membiayai biaya operasi non personalia. Dengan demikian masyarakat berkewajiban untuk menanggung biaya pribadi peserta didik, seperti seragam,buku dan alat tulis,sepatu,tas sekolah serta biaya transport peserta didik dari rumah ke sekolah.

Dana Program Sekolah Gratis yang bersumber dari APBD Provinsi disalurkan langsung kerekening sekolah sekolah swasta, madrasah Negeri/ Swasta. Sedangkan untuk sekolah negeri non madrasah dananya ditransfer ke Kas daerah Kabupaten/Kota masing masing. Sedangkan Dana Program Sekolah Gratis yang bersumber dari APBD Kabupaten/Kota disalurkan oleh Pemerintah Kabupaten/Kota kepada masing masing sekolah baik negeri maupun swasta dan madrasah negeri maupun swasta Dana Program Sekolah Gratis diutamakan digunan untuk :

1) Pembiayaan seluruh kegiatan dalam rangka penerimaan siswa baru 
2) Pembelian buku referensidan buku teks pelajaran untuk dikoleksi diperpustakaan pembiayaan kegiatan pembelajaran remedial,pembelajaran pengayaan, ekskul.

3) Pembiayaan ulangan harian ,ulangan umum,ujian sekolah dan laporan hasil belajar siswa

4) Pembelian bahan bahan habis pakai seperti buku tulis,kapur tulis,pensil bahan praktikum,buku induk siswa,buku investaris.

5) Pembiayaan langganan daya dan jasa seperti listrik,air,telpon,internet,dan biaya pengelolaan lingkungan,termasuk untuk pemangan baru jika sudah ada jaringan disekitar sekolah.

6) Pembiayaan perawatan sekolah yaitu pengecatan, perbaikan atap bocor,perbaikan pintu dan jendela, perbaikan meubeler.

7) Pembayaran honorarium bulanan guru honor dan tenaga kependidikan honorer.

8) Pembayaran honorarium tenaga honorer yang membantu administrasi program sekolah gratis pada SD/MI

\subsection{Kerangka pikir}

9) Pengembangan profesi guru seperti pelatihan, kelompok kerja guru/musyawarah guru mata pelajaran dan kelompok kerja kepala sekolah/musyawarah kerja kepala sekolah.

10) Pemberian bantuan biaya transportasi bagi siswa miskin yang menghadapi masalah biaya transport dari dan kesekolah

11) Pembiayaan pengelolaan program sekolah gratis seperti alat tulis kantor,penggandaan,surat menyurat,insentif bagi bendahara dalam rangka penyusunan laporan program sekolah gratis dan biaya transportasi dalam rangka pengambilan dana program sekolah gratis di Bank/Kantor pos.

12) Pembelian komputer untuk kegiatan belajar siswa,maksimum 2 set untuk SMA/SMK/MA

13) Pembayaran honorarium walikelas dan wakil kepala sekolah serta kelebihan mengajar (lebih dari 24 Jam) secara nyata berdiri di depan kelas yang belum dialokasikan dari sumber dan lain.

Gambar 2.3.

Skema Kerangka Pemikiran

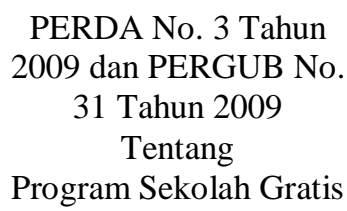




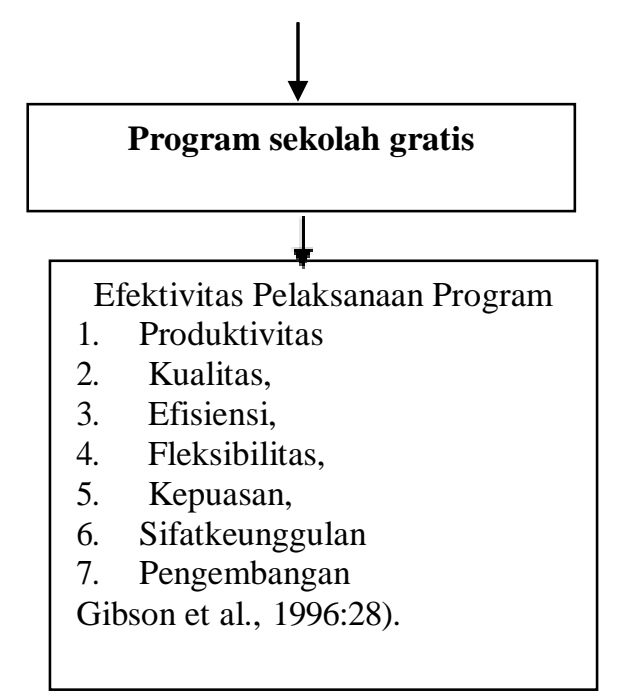

\section{PEMBAHASAN}

\subsection{Kualitas pada efektivitas Program Sekolah Gratis}

Tahun 2009 ini pemerintah telah memutuskan untuk memenuhi ketentuan UUD 1945 pasal 31 tentang alokasi APBN untuk pendidikan sebesar $20 \%$. Sehingga akan tersedianya anggaran untuk menaikkan pendapatan guru, terutama guru pegawai negeri sipil (PNS)

.Pemerintah daerah wajib untuk memenuhi kekurangannya dari dana APBD yang ada. Agar proses belajar-mengajar pun tetap terlaksana tanpa kekurangan biaya.

Salah satu ukuran kualitas pendidikan yang sering digunakan adalah Indeks Pembangunan Pendidikan Untuk Semua atau education for all (EFA). Data tahun 2011 menunjukkan bahwa Indeks Pembangunan Pendidikan di Indonesia berada di peringkat 69 dari 127 negara, merosot dibandingkan tahun 2010 yang berada pada posisi 65 . Indeks yang dikeluarkan oleh UNESCO ini lebih rendah dibandingkan Brunei Darussalam (34), serta terpaut empat peringkat dari Malaysia (65).

Ada banyak penyebab rendahnya indeks pembangunan pendidikan di Indonesia. Salah satunya adalah rendahnya tingkat partisipasi penduduk usia sekolah di semua jenjang pendidikan. Indikator yang paling sederhana untuk mengukur tingkat partisipasi tersebut adalah angka partisipasi kasar (APK) atau rasio jumlah siswa berapa pun usianya yang sedang sekolah di tingkat pendidikan tertentu terhadap jumlah penduduk dengan kelompok usia yang berkaitan dengan jenjang pendidikan tertentu.

\subsection{Efisiensi pada efektivitas Program} Sekolah Gratis

Pada pelaksanaan Program Sekolah Gratis secara umum sangat membantu masyarakat miskin, seperti perkembangan jumlah lembaga pendidikan yang terus bertambah, pemerataan kesempatan memperoleh pendidikan, menurunnya angka putus sekoah, Buta aksara setiap tahun semakin menurun.Seiring dengan perkembangan pembangunan pendidikan di Provinsi Sumatera Selatan jumlah lembaga pendidikan terus bertambahan setiap tahunnya hal tersebut karena pemerintah secara terus menerus melaksanakan pembangunan gedung sekolah baik unit sekolah baru maupun penambahan ruang kelas untuk sekolah negeri maupun swasta berikut dapat dilihat 
pada data perkembangan lembaga

pendidikan di Sumatera Selatan

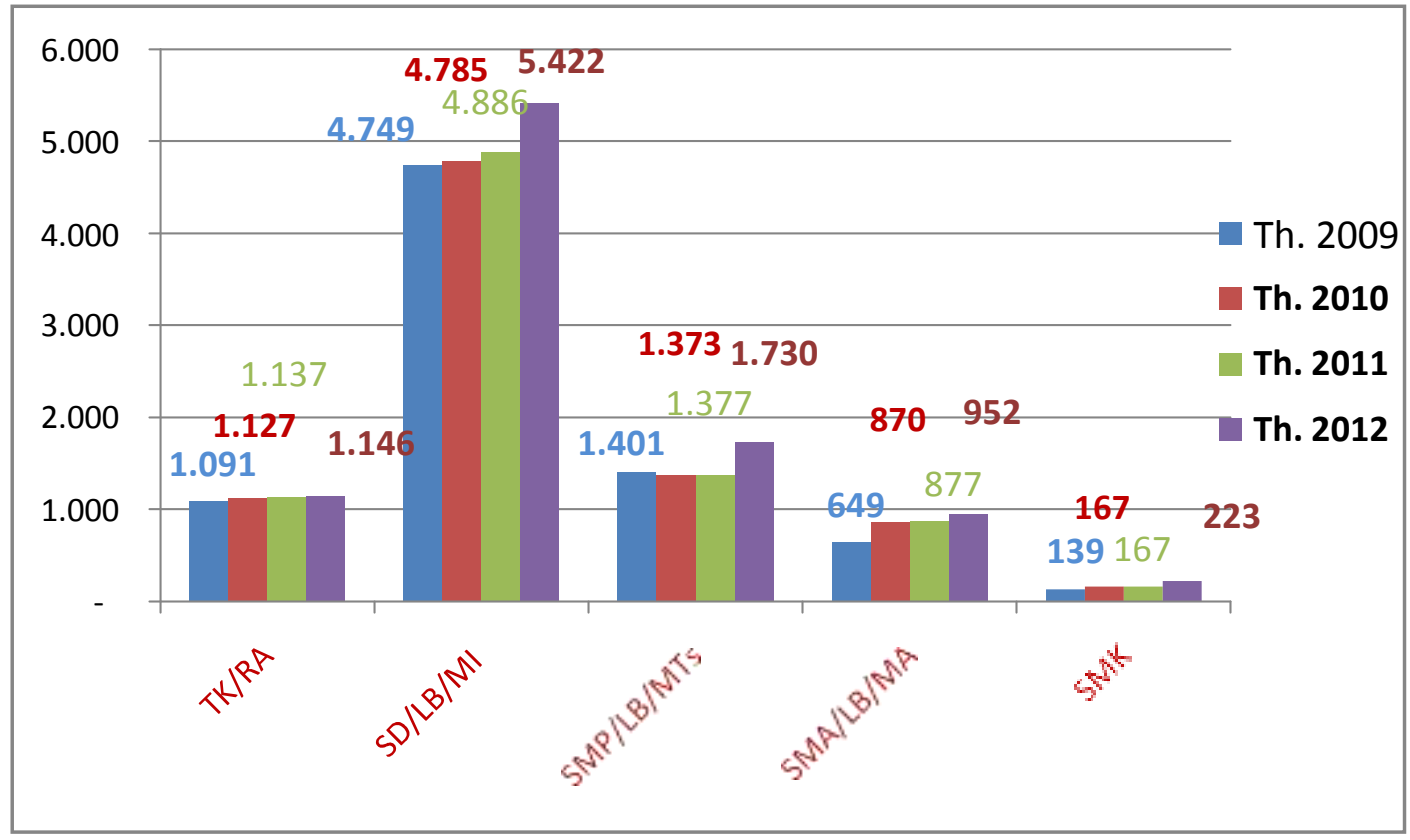

Grafik 1 Perkembangan Sekolah

\subsection{Fleksibilitas pada efektivitas Program Sekolah Gratis}

Dalam penyelenggaraan Program Sekolah Gratis telah dibentuk organisasi baik ditingkat provinsi maupun ditingkat kabupaten/kota yang disebut TIM Manajemen Provinsi, TIM manajemen dan Tim Pelaksana. Masing masing memiliki tanggungjawabnya. Pada Tim Manajemen Provinsi yang telah menentapkan bantuan tiap Kabupaten/Kota. Namun fleksibelitasnya dalam sosialisasi, pendataan, koordinasi, monitoring dan evaluasi belum maksimal . Sedangkan Tim manajemen kabupaten/Kota yang menetapkan alokasi bantuan tiap sekolah/madrasah belum secara berkala melakukan pembinaan atau sosialisasi. Tidak fleksibel Tim kabupaten/Kota berkomunikasi baik secara lisan maupun secara tertulis kepada Tim Manajemen Provinsi yang menyangkut masalah masalah pada pelaksanaan program sekolah gratis di SMA Negeri 16 Palembang maupun pertanggungjawaban. Tidak fleksibel pula pada perencanaan seperti keluhan Tim Pelaksana pada sekolah sekolah tentang format pertanggungjawaban yang tidak beragam dan belum adanya SOP pelaksanaan program yang seharusnya sudah ada karena program ini sudah masuk pada tahun ke enam pelaksanaannya. Pada pelaksaan Pengelolaan dana di SMA negeri 16 Palembang, pengelolaan dana dipisahkan yaitu dana program sekolah gratis sudah dijalankan sejak tahun 2009 dan yang mengelolanya sudah lima tahun tidak berganti. Ini menunjukkan fleksibilitas tidak berjalan seperti yang dikehendaki karena tidak adanya penyengaran pengelolaan dana Program Sekolah Gratis atau perubahan perubahan yang berarti lainnya. 


\subsection{Kepuasan pada efektivitas Program Sekolah Gratis}

Ada beberapa factormengukur tingkat kepuasan masyarakat terhadap pelaksanaan program sekolah gratis yaitu : tangibles, realibility, responsiveness, assurance, emphty. Yang dimaksud:

Tanggibles :Pada kondisi tangibles masyarakat perkotaan dipungut biaya cukup besar dalam proses pembelajaran, Sedangkan pelaksanaan program Sekolah Gratis sangat besar manfaatnya bagi sekolah sekolah negeri yang berada dipinggiran kota seperti SMA negeri 16 Palembang. Dimana siswa tidak dipungut biaya mulai dari proses penerimaan sampai proses belajar.Namun bagi siswa SMA negeri 16 dengan fasilitas sarana dan prasarana yang dimiliki sekolah masih dirasakan belum memberikan kenyamanan.

Reliability (Keandalan) : suatu pelayanan dengan cepat dan tepat tanpa membeda bedakan dalam menanamkan kepercayaan pada masyarakat. Pada tahun 2010 dan tahun 2011 Tim Provinsi Sumatera Selatan telah melaksanakan evaluasi Program Sekolah Gratis. Banyak permasalahan yang perlu mendapat perhatian utamanya Tim Manajemen Kabupaten/Kota tidak tepat waktu dalam administrasi pelaporan, akibatnya pencairan dana kerekening penampungan terlambat sehingga keperluan pendidikan tidak dilaksanakan secara maksimal. Responsiveness : merupakan penilaian tentang sikap Tanggap pemerintah daerah terhadap keluhan stakeholder ,kritikan dan saran masyarakat melalui beberapa cara ke media pengaduan. Selama ini tim monitoring dan evaluasi hanya mengambil sampling pemeriksaaan ke sekolah sekolah yang ada dikabupaten/Kota. Hal ini menurut penulis belum optimal karena sampai saat ini belum ada Surat Keputusan Walikota Palembang yang berhubungan dengan alokasi anggaran pendamping Program Sekolah Gratis. Artinya Tim

Manajemen Kota Palembang dalam melaksanakan tugasnya belum berpedoman pada ketentuan yang berlaku.

Assurance : merupakan penilaian masyarakat terhadap jaminan atas pelayanan yang dilaksanakan pemerintah terhadap program sekolah gratis. Image yang baik akan menghasilkan penilaian masyarakat yang baik .

Emphaty : merupakan penilaian atas kesungguhan dan ketegasan Tim dalam usaha memenuhi kepuasan masyarakat

\subsection{Sifat Keunggulan pada efektivitas Program Sekolah Gratis}

Program Sekolah Gratis di Sumatera Selatan memiliki keunikan (Unique Service), karena mampu mengcaver pelaksanaan pendidikan dari semua tingkat dan berlaku pada 17 Kabupaten/Kota yang ada dengan dana APBD yang sangat besar sejak tahun 2009 s/d tahun 2013 telah mengeluarkan dana sebesar Rp. 1.676.707.525.382.Program Sekolah Gratis juga memiliki harga/nilai(Price/Value). Pengalaman konsumen (Customer Experience) selama ini atas kondisi pendidikan di Sumatera Selatan menjadi lebih baik

\section{KESIMPULAN}

Ada beberapa hal yang menjadi perhatian bersama yaitu :

1. Belum efektifnya pelaksanaan Permedagri nomor 13 Tahun 2006 yang dirasakan mekanismenya berbelit..

2. Belum efektifnya Standar Pelayanan Minimum di SMA Negeri 16 Palembang. 
3. Belum efektifnya Penyediaan sarana dan prasarana pendidikan di SMA Negeri 16 Palembang .

4. Belum efektifnya pengembangan dan pembinaan berkala dari Tim Provinsi ke kabupaten/Kota serta Tim Kabupaten/Kota ke tim Manajemen Sekolah ke sekolah SMA Negeri 16 Palembang

5. Belum efektifnya pengawasan ke SMA Negeri 16 Palembang tentang penggunaan sekolah gratis.

6. Belum efektifnya sangsi yang tegas pada kabupaten Kota yang tidak melaksanakan MOU dana Sharing dengan Kabupaten dan belum satu formnya sekolah sekolah sehingga masih ada sekola yang menolak program sekolah gratis yang di programkan pemerintah Provinsi.

\section{Saran}

\section{a. Praktis}

1. Perlu adanya penerlaahan terhadap Perda Nomor 16 tahun 2011 tentang perubahan atas peraturan daerah Nomor3 tahun 2009.

2. Perlunya melakukan sosialisasi lanjutan Program Sekolah Gratis sehingga adanya pemahaman yang sama mengenai penggunaan dan pertanggungjawaban keuangan

3. Pemerintah Sumatera Selatan untuk lebih intensif melakukan pengawasan terhadap SMA Negeri 16 Palembang dan sekolah yang lain terhadap pelaksanaan atau pengeolaan Program sekolah Gratis.

\section{b. Saran Akademik}

1. Disarankan dalam penelitian ini dilakukan pendataan ulang jumlah siswa dan terbentuknya wadah yang permanen dalam mengelolaprogram program unggulan di sumatera Selatan. Bukan dalam bentuk tim.

\section{DAFTAR PUSTAKA}

Ali, Faried dan Alam,Andi Syamsu, 2012, Studi Kebijakan Pemerintah, Bandung, Refika Aditama.

Ali, Faried dan Alam, Muhidin, Nurlina, 2012, Hukum Tata Pemerintahan, Bandung, Refika Aditama

Grindle ,Marille,S. 1980. Polities and Policy Implementation in The Third World.New York : Princeton University Press

Gibson,J.L.Ivancevich,J.M.and Donnely,J.H,1989, Organisasi dan Manajemen

(alih bahasa : Adiarni, Nunuk), Edisi ke empat,Jakarta,Penerbit Erlangga

Harold G. Shane, 2002. Arti Pendidikan Bagi Masa Depan , Bumi Aksara 2002

Handayani ningrat,

Suwarno,1994,Pengantar ilmu Administrasi dan manajemen , Jakarta ,CV.Haji Masagung

Irawan, Prasetya, 2000. Logika dan prosedur Penelitian, Jakarta, CV. Infomedia

,Yeremias T ,2008 Enam Dimensi Strategis Administrasi publik

Yogjakarta , Gava Media

Indrawijaya, Adam Ibrahim, 2010, Teori

Prilaku dan Budaya Organisasi, Bandung, Refika Aditama

Indrawijaya, Adam Ibrahim, dan Pronoto . Juni 2011, Revitalisasi Administrasi Pembangunan (berbasis Jatidiri dan Karakter Bangsa Dalam Pembangunan Nasional ), Bandung. Alfabeta 
Islamy ,M. Irfan 2002 , Sery Policy Analysis ,Program Pascasarjana Universitas

Brawijaya , Malang

Keban,Yeremias T , 2008, Enam Dimensi

Strategis Administrasi Publik.

Yogjakarta : Gava Media

Jones,Charles O,1991,Pengantar kebijakan publik (publik Policy), dalam Natsir Budiman ed, Rajawali,Jakarta

Nugroho Riant, 2003. Kebijakan Publik Formulasi ,Implementasi dan Evaluasi.Jakarta PT. Alex Media Komputindo

Nugroho Riant, 2006. Kebijakan Publik untuk negara Negara berkembang, Jakarta :Pt,. Elex Media Komputindo

Neo,SiongBoon and Chen,Geraldine,2007,Dynamic Governance,Singapore,World Scientific Publishing Co.Pte.Ltd.

Moenir H.A.S.2010, Manajemen Pelayanan Umum di Indonesia, PT. Bumi Aksara : Jakarta

Miles, Mathew B dan Huberman AMichael 2009. Analisis Data Kualitatif (alih bahasa :tjetjep Rohendi Rohidi),Jakarta,Indonesia University Press.

Makmur,2009, Teori Manajemen Strategik Dalam pemerintahan dan Pembangunan,Bandung , Refika Aditama

Mudyahardjo Redja, 2001. Pengantar Pendidikan. PT.Raja Grafindo; Jakarta

Mazmanian, Daniel A and Paul Sabatier, 1983, Implemantion And Public Policy,

Foresman and Company, USA

Ndraha, Taliziduhu, . 2003. Kybernology jilid I dan II. Jakarta : Rineka Cipta
2004.

PemberdayaanMasyarakatdilihatda ripresfektifKybernolofi, Unpad IIP , Jakarta.

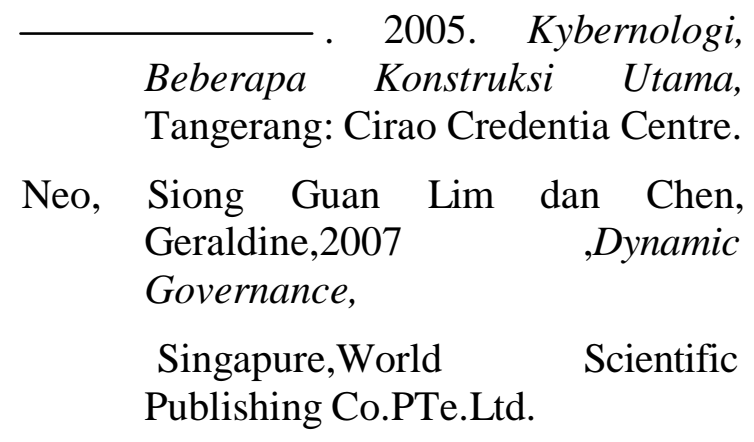

Nugroho Riant, 2003, Kebijakan publik Formulasi,Implementasi dan Evaluasi

.Jakarta .PT. Elex Media Komputindo

Nugroho Riant, 2006, Kebijakan Publik untuk Negara Negara Berkembang.

Jakarta .PT. Elex Media Komputindo

Ripley,Randall.B. And Franklyn,Grace A.1986. Policy Implementation

Bureaucratic.Chichago : the Dorcey Press

Rusli Budiman.2013. Kebijakan Publik Membangun Pelayanan Publik Yang

Responsif, All Riights reserved,

Pasolong,Harbani. $2007 . \quad$ Tiori Administrasi Publik,Alfabeta, Bandung

Parson, Wayne 2005,Public Policy ,Jakarta,Prenada Media

Pamudji, S,1993, Kepemimpinan Pemerintahan di Indonesia, Jakarta,Bumi Aksara

Priyono, Edi. 2008. "Perangkap Pendidikan Gratis". Harian Suara Pembaruan, 11

Februari 2008. 
Pranaka,A.M.W.dan

Prijono,S.Onny,1996,Pemberdayaa $n:$ Konsep Kebijakan

Dan implementasi ,Jakarta ,Centtre For Strategic and Internasional

Studies.

Sardjunani, Nina. 2008. "Tinjauan Umum Wajar Dikdas 9 Tahun: Hasil Studi

Bappenas dan Bonus Demografi". Di dalam Fajarini, 2008. Prosiding

Seminar Wajib Belajar 9Tahun Gratis, Mungkinkah? Jakarta,30 April

2008. Jakarta: Balitbang Depdiknas didukung oleh Kemitraan Australia

Indonesia.

Streers Richard, 1985, Efektivitas Organisasi (Kaidah Perilaku) Cetakan Kedua, Jakarta. Erlangga

Siagian Sondang P 1997 .Organisasi ,kepemimpinan dan prilaku administrasi CV.Haji Mas Agung: Jakarta

Siagian Sondang P 2006. Manajemen Modern, Gunung Agung : Jakarta

Subarsono,AG.2008.Analisis kebijakan Publik:Konsep,Teori dan

Aplikasi,Pustaka

Pelajar,Yogjakarta.

Soharto ,Edi,2010, Membangun masyarakat Memberdayakan Rakyat (kajian

Strategis Pembangunan

Kesejahteraan Sosial dan pekerjaan Sosial)

Bandung ,Refika Aditama.

Wibawa,Samodra.1994, Kebijakan Publik,Proses dan Analisis, Jakarta. Intermedia

Wibawa,Samodra DKK.1997. Evaluasi Kebijakan Publik, Jakarta :PT. Raja
Grafiindo Persada

Wahab,Solihin Abdul,2005. Analisis Kebijaksanaan dari Analisis ke

Implementasi Kebijaksanaan negara, PT. Bumi Aksara,Jakarta

Winarno ,Budi,2008.Kebijakan Publik Teori dan Proses. Edisi Revisi.Penerbit

Med Press.Yogjakarta.

Tjokroamidjojo, Bintoro, 1995.

Perencanaan Pembangunan :CV Haji Mas

Agung, Jakarta

John W Creswell, (2010), Research Design Yogjakarta : Pustaka Pelajar

Lain lain :

Pariata Westra, http://respository.unhas.Ac.id/bitstr eam/handle/pdf?sequence

Saifuddin

Anhari,http://carapedia.com/penger tian-defenisi-program-info 2048 html :Diakses 21/Feb/2012

Shindhunanta.http://carapedia.cam/pengert ian-defenisi-programinfo2048.hhtml;Diakses 21/Feb/2012

\section{Dokumen-Dokumen}

Undang Undang Dasar 45

Undang Undang RI Nomor 32 tahun 2004 Tentang PemerintahanDaerah

Undang Undang Republik Indonesia nomor 20 tahun 2003 tentang Sistem Pendidikan Nasional

BadanPusatStatistik Indonesia, Data dan InformasiKemiskinanTahun 2011

Centre for Political Studies,Otonomi Potensi Masa Depan Republik

Indonesia,Jakarta : PT. Gramedia Pustaka Utama, 2001 
Dinas Pendidikan Provinsi Sumatera Selatan, Data pokok Provinsi Sumatera

Selatan tahun 2009/2010 ,Palembang 2010

KomitePenanggulanganKemiskinan Indonesia, DokumenInterimStrategi

PenanggulanganKemiskinanSebuahKeran gkaProsespenyusunan

StrategiPenanggulanganjangkaPanjang

PemerintahProvinsiSumateraSelatan, 2009-2014, Rencanapembangunan

\section{JangkaPanjangProvinsiSumateraSelatan}

Profil Pendidikan Provinsi Sumatera Selatan tahun 2010

Rencana Strategis Departemen Pendidikan Nasional 2005 - 2009.

Rencana Strategis Departemen Pendidikan Nasional 2008-2013.

Rencana Strategis Dinas Dispora Kota Palembang

Peraturan Daerah Provinsi Sumatera Selatan Nomor 3 Tahun 2009 tentang Penyelenggaraan Program Sekolah Gratis di Provinsi SumateraSelatan.

Peraturan Gubernur Provinsi Sumatera Selatan Nomor 31 Tahun2009 tentang Pedoman Penyelenggaraan Sekolah Gratis di Provinsi Sumatera Selatan.

Peraturan Walikota Palembang Nomor 796 Tahun 2009 tentang Penetapan besaran/satuan biaya dana bantuan operasional sekolah.
Peraturan Daerah Kota Palembang No. 9 Tahun 2008 tentang Pembentukan, Susunan Organisasi dan Tata Kerja Dinas Daerah Kota Palembang.

Instruksi Presiden No. 5 Tahun 2006tentang Gerakan NasionalPercepatan Penuntasan WajibBelajar Pendidikan Dasar 9 Tahun danPemberantasan Buta Aksara.Jakarta: Sekretariat Negara RI.

Balitbangda Provinsi Sumatera Selatan. 2011. Laporan PenelitianKajian Program Sekolah Gratis Sumatera Selatan Tahun 2011.Palembang.

Lakip Dinas Pendidikan Provinsi Sumatera Selatan tahun anggaran 2012.

Lakip Dinas Dispora Kota Palembang Profil Sekolah SMA Negeri 16 Lebak Murni Kota Palembang 